\title{
JAPANESE EXPERIENCE IN ENSURING SOCIAL AND ECONOMIC SECURITY IN THE NATIONAL SECURITY SYSTEM OF THE COUNTRY
}

\author{
CShvaiba D., ORCID: 0000-0001-6783-9765, Ph.D., Belarusian Trade Union of Workers \\ of Chemical, Mining and oil Industries; Belarusian National Technical University, \\ Minsk, Belarus, shvabia@tut.by
}

\section{ЯПОНСКИЙ ОПЫТ ОБЕСПЕЧЕНИЯ СОЦИАЛЬНО-ЭКОНОМИЧЕСКОЙ БЕЗОПАСНОСТИ В СИСТЕМЕ НАЦИОНАЛЬНОЙ БЕЗОПАСНОСТИ СТРАНЫ}

\author{
СШвайба Д. Н., ORCID: 0000-0001-6783-9765, канд. экон. наук, Белорусский профсоюз \\ работников химической, горной и нефтяной отраслей промышленности; Белорусский \\ нащиональный технический университет, г. Минск, Беларусь, shvabia@tut.by
}

Abstract. It should be noted that the global practice of ensuring the socio-economic security of the state is wide and diverse. This article discusses the practice of its enforcement in Japan. This state has accumulated significant financial and economic experience, including in matters of social and economic security. Studying the financial and economic dynamics of Japan, we will focus on the financial, economic and political aspects of ensuring socio-economic security of the state, the accompanying institutional circumstances. Scientists have noted that the financial and economic development of Japan in the post-war period is now a traditional case of realization of significant competitiveness of the state economy, in General, and some individual sectors of the economy, in particular, in the criteria of energy and raw material resources deficit. As a state with few natural resources; which was backward in almost all respects seventy years ago, Japan has transformed into a prosperous power in the world in terms of financial and economic development. However, the rise of the competitive economy is not determined by the involvement of an increasing number of means of the production process, but by the increase in the effectiveness of their application, the indicators of which act as financial and economic factors of the macro-competitiveness of the sectors of the economy, the state economy are innovative. At the same time, in recent years, the labor index as a whole had a negative impact on the financial and economic recovery, which, in our opinion, is considered a harbinger of, in-1, increasing unemployment; in-2, the situation of population aging. However, the rise in the productivity of the production process during the same time, leveled the negative impact of the presented factor and provided a cumulative recovery of the economy.

Аннотация. Необходимо обратить внимание, что глобальная практика обеспечивания социально-экономической безопасности государства широка и разнообразна. В статье рассматривается практика ее обеспечивания в Японии. Этим государством накоплен существенный финансово-экономический опыт, в том числе и в вопросах обеспечивания социально-экономической безопасности. Исследуя финансово-экономическую динамику Японии, будем концентрировать внимание на финансово-экономических и политических моментах обеспечивания социально-экономической безопасности данным государством, сопутствующих этому институциональных обстоятельствах. Учеными замечено, что финансово-экономическое становление Японии в послевоенный этап представляется сейчас традиционным случаем реализации значительной конкурентоспособности экономики 
государства, в общем, и некоторых отдельно взятых секторов экономики, в частности, в критериях дефицита энергетических и сырьевых ресурсов. Будучи государством со небогатыми природными ресурсами; которая еще семьдесят лет назад была по почти по всем показателям отсталой, Япония трансформировалась в преуспевающую державу в мире по уровню финансово-экономического развития. Впрочем, подъем конкурентной экономики определяется не вовлечением все более значительного количества средств производственного процесса, а увеличением результативности их применения, показатели которой выступают, как финансово-экономические факторы макро-конкурентоспособности секторов экономики, государственной экономики имеют новаторский характер. При этом в последние годы показатель труда в целом оказывал отрицательное воздействие на финансово-экономический подъем, что, считается предвестником, во-первых, увеличивающейся безработицы; вовторых, ситуации старения населения. Впрочем, подъем результативности производственного процесса за это же время, нивелировал отрицательное воздействие представленного фактора и обеспечивал совокупный подъем экономики.

Keywords: socio-economic security, government, society, enterprise, employee, threat, security, interests, economics, analysis, system.

Ключевые слова: социально-экономическая защищенность, государство, общество, предприятие, работник, угроза, защищенность, интересы, экономика, анализ, система.

The study of more than 20 definitions of 'socio-economic security' formulated by economists of the post-Soviet space, definitions from official documents of Hungary, Poland, Lithuania, Ukraine, the Russian Federation, as well as more than 10 definitions given by scientists of developed countries (USA, Canada, Germany, France, Spain, Japan), demonstrates that for any group of States the introduction of different approaches is typical. Thus, in post - Soviet States, the bulk of definitions is given by means of the prism of 'interests', in post - socialist States through the measurement of the impact on global security, in developed States - through the concept of 'sustainability' [1, p. 28; 2, p. 98; 3, p. 75].

It should be noted that the global practice of ensuring the socio-economic security of the state is wide and diverse. This article discusses the practice of its enforcement in Japan. This state has accumulated significant financial and economic experience, including in matters of socio-economic security [4-5].

Studying the financial and economic dynamics of Japan, we will focus on the financial, economic and political aspects of ensuring socio-economic security of the state, the accompanying institutional circumstances [6; 7, p. 61; 8, p. 143].

Scientists have noted that the financial and economic development of Japan in the post-war period is now a traditional case of the implementation of significant competitiveness of the state economy, in General, and some individual sectors of the economy, in particular, in the criteria of energy and raw materials shortages.

As a state with few natural resources; which was backward in almost all respects seventy years ago, Japan has transformed into a prosperous power in the world in terms of financial and economic development. However, the rise of a competitive economy is not determined by the involvement of an increasing number of means of the production process, but by the increase in the effectiveness of their application, the indicators of which act as financial and economic factors of macro-competitiveness of sectors of the economy, the state economy are innovative. At the same time, in recent years, the labor index as a whole had a negative impact on the financial and 
economic recovery, which, in our opinion, is considered to be a precursor, in-1, increasing unemployment; in-2, the situation of population aging. However, the rise in the productivity of the production process during the same time, leveled the negative impact of the presented factor and provided a cumulative recovery of the economy.

Now more and more indisputable is the conclusion that the rise in productivity in the sectors of the Japanese economy is guaranteed by the following reasons:

-modern technologies of the production process as a result of $\mathrm{R} \& \mathrm{D}$;

-the original system of labor organization as a technology of intellectual resource management, which increases its productivity;

-Japanese systems of organization and management of the production process.

Since the mid $50 \mathrm{~s}$ of the XX century, investments in scientific and technological progress have been at the center of interest of the government and companies of Japan. Investment in R \& D has increased 12-fold over the past 30 years, which is considered the highest rate of recovery in the world. Since 1989, Japan's GNP expenditures on science and technology, as well as civil R \& d expenditures, have been the highest in the world. Analysis by the Public policy Institute in the field of science and technology, have demonstrated that the total integral indicator of the importance of the progress of Japanese science 2 times higher than in Germany, France or Britain [9, p. 26].

A specific feature of $\mathrm{R} \& \mathrm{D}$ expenditures in Japan is the predominant financing of $\mathrm{R} \& \mathrm{D}$ by major corporations and the increasing importance of R \& D structures within corporations, which makes it possible to achieve a closer integration of science and the production process. As a result, even with lower total R \& D expenditures of Japanese producers in comparison with American ones, the products of the former are more competitive.

The peculiarity of the introduction of R \& D in Japan is considered to be 1 of the largest (at the US level) for scientists and innovators in the total mass of workers. The results of individual studies showed that in Japan 50\% of employees participate in innovation, each of which accounts for 12.8 implementations per year. At the same time, the composition of the subjects of the internal system of rationalization in Japan does not consist of engineers and technicians (as, for example, in the US), but in a key way of ordinary employees. This indicates the high quality of the Japanese workforce.

At the same time, intensive participation in $\mathrm{R} \& \mathrm{D}$ is not a single contribution of Japanese companies' employees to increase the efficiency of the production process. An important role in this process is played by intellectual and highly skilled labor resources as a factor in the production process, characterized by productivity, which since 1955 has increased by 17.7 times.

At the same time, the increasing labor productivity in the sectors of the Japanese economy is due, first, to the quality of the labor force itself; second, to the unique system of labor organization. The quality of Japan's workforce is primarily based on the highest educational level of employees. Illiteracy in Japan was eliminated at the end of the XIX century. As a result of the established tradition of respect for education, a large number of graduates of secondary schools in Japan, continuing their studies in higher education (41\%), in comparison with the UK (32\%), France (38\%), Germany (33\%) and after the United States (45\%) occupies the 2nd place in the world. As a consequence, Japan has more engineers with higher education than other highly developed countries.

It should be added that the existing education system in Japan is built taking into account the needs of the economy. Thus, more fundamental knowledge that meets all the requirements, it is possible to get just in the technical institutes, focusing on the exact Sciences, which ensures the needs of the developed production system of Japan in trained personnel. It is no less important to 
increase the efficiency of the production process that promising managers and workers have the opportunity to train in Japanese corporations.

Another way to increase productivity in different sectors of the Japanese economy is a unique form of labor relations, which, according to most researchers, has made the maximum contribution to the financial and economic growth of the state. It is based on:

-indefinite employment systems;

-system of staff rotation;

-the system of training in the workplace;

-reputation system;

-remuneration systems.

Any of these systems with their positive impact on productivity has been studied quite well, which is reflected in scientific works. Without dwelling in detail on each of these systems separately, we demonstrate that they themselves, being interdependent, are represented by the subjects of an integrated system of organization of labor relations, the key function of which is to increase productivity. Thus, it is necessary to designate special space in it of system of termless employment.

The system of on-the-job training, being essentially a permanent job to increase the skills of employees throughout their careers, which of course involves certain costs on the part of the employer, would be meaningless without the system of indefinite employment. The same can be said about the system of personnel rotation, the essence of which is to move every 2-3 years employees both vertically and horizontally, which gives them the opportunity to get a maximum idea of the specifics of a certain production process and reduces, thus, the possibility of making unprofessional decisions.

It is clear that this is effective only if the employer involves the use of workers for a long period. At the same time, career advancement is also associated with work experience. As a result, the connection of these components increases the system of remuneration, which is considered one of the components of the overall system of organization of labor relations; the amount of remuneration of employees is dependent on the length of service, position, etc. As a result, Japanese enterprises are developing a positive climate, based primarily on cooperation and assistance, which leads to a rise in productivity.

However, the quality of labor increases the competitiveness of economic sectors not only at the expense of productivity. People, as a key buyer of the products manufactured in the country, demand for products, encouraging enterprises to innovate. Thus, a significant educational level, on the one hand, increases productivity, and, on the other - creates a more demanding demand, increasing in both cases the dynamics of innovative processes, and, therefore, competitiveness.

This is evident in the most competitive sectors of the economy. For example, the products of the automotive industry in Japan, characterized by the highest productivity, has a demanding customer in the face of the Japanese themselves. And often the employees of the provided industry, who are more qualified, the more demanding as buyers.

The 3rd factor of increase in productivity of production process designated by us-the Japanese systems of the organization and management of production processes. The individuality of production management systems, which may be considered Japanese in origin, lies in their strict focus on increasing productivity through cooperation rather than competition. In this regard, these systems are very typical as a system of 'just-in-time' and 'total quality control' [10, p. 19].

Among other things, it is necessary to identify the political aspects of ensuring the competitiveness of the Japanese economy. The range of opinions on the role of state regulation of 
the Japanese economy is significant: from 'Corporation Japan' - representation of the Japanese economy as a large company headed by the government, to the 'classical' model of market economy with the least interference of the country in the functioning of the market.

The last assumption on the 1st look, seems more reasonable. At the current stage in Japan, only 4 state corporations (post - Telegraph, mint, forestry, printing house for the publication of collections of laws and official statistics), which indicates a small share of state property.

Low expenditures on state aid for development (at the level of $0.3 \%$ of GDP), lower in comparison with other developed countries, the volume of government investments in R \& D (about $20 \%$ of total costs), insignificant in the number of employees of civil servants - all this seems to confirm the assumption of insignificant impact of the Japanese government on the financial and economic situation. However, this opinion, in our opinion, is wrong. State regulation of economic sectors in Japan is based on completely different principles in comparison with the similar experience of Western countries and, in accordance with this, the classical characteristics cannot provide an adequate assessment.

In 1, according to the American Japanologist D. I., Okimoto, "the degree of confidence of the Japanese government to the natural development of the situation in the market low criteria" [10, $p$. 17]. This determines the strategy of state intervention in the economy.

The strategic objective remains constant: business and government work together to increase the global competitiveness of the Japanese economic sectors. So undeniable harmony in the choice of government and the main corporations' areas of reference of the global competition gave a pretext for the use of the expression 'Corporation Japan'. While this view is somewhat true, it is generally seen as very simple and does not reflect the actual relationship between the government and Japanese business.

One of the individuals of state regulation of the Japanese sectors of the economy is considered to be extremely developed state programming, including the development of long-term forecasts, medium-term projects of socio-economic development of sectors of the economy, annual plans of expenditure of the state budget, which in relation to Japan may, though with certain assumptions be considered as short-term intentions for the development of the state economy.

The Japanese government often enjoys direct administrative intervention. The way of its implementation, in our opinion, is considered an important feature of state regulation of the Japanese economy. The fact is that administrative intervention in Japan is often not carried out through the adoption of appropriate laws, but through the Council of equality to the business community of a more desirable, strategically justified vector of development of sectors of the economy that are de jure non-binding. However, in practice, government councils are adopted as instructions for action, which is considered the result of mutual trust of the government and the business environment. This "almost never happens such, that the top is unilaterally given any decree, and entities with fright tried to resist. Faster from private owners the application to take measures of administration then the government proceeds to actions" [10, p. 21] arrives.

At the same time, an important condition for the effectiveness of this method is the presence of a significant number of 'semi-governmental' organizations that have an impact on the economic sector on a fairly wide range of financial, economic and social issues, as well as the presence of a large number of committees at the government bodies, which consist, as a rule, of representatives of business and the scientific environment and are designed to identify the 'direct merger' of the state apparatus and business.

In tactical terms, the country's intervention is based on the concept of 'life cycles' of the industrial sector. Due to the low market demand in certain sectors of the economy, large-scale intervention is carried out at the initial turn of the 'life cycle'. As soon as this industry gets absolute 
development, and demand reaches the highest point, intervention quickly decreases. But when the economic sector plunges into a situation in which there are difficulties, the loss of a leading position, the oversaturation of the market, the depreciation of the stock exchange rate, overcapacity, the intervention increases again.

Considering the institutional circumstances of ensuring the socio-economic security of the state, we will study these circumstances in terms of their impact on the competitiveness of economic sectors, which is identical to the impact on the dynamics of innovative activity. At the same time, we note that in accordance with the definition of socio-economic security proposed by us in the first paragraph, the latter is achieved as a result of the interaction of financial, economic and political factors in positive institutional criteria.

The Japanese economy is experiencing a strong impact of informal structures on financial and economic dynamics. At the same time, it is present in both employer - employee and government - business relations, practically penetrating the economy at the micro, meso and macro levels. For example, the previously mentioned system of indefinite employment, which lies in the essence of labor relations in large and medium-sized enterprises, as well as in public administration, is in fact in no way de jure regulated. It is presented as an oral agreement, the stability and inviolability of which shows a lot. Or the Japanese tradition of respect for education, which plays an important role in increasing the qualification of labor, and, therefore, its productivity, which is one of the confirmations of the interaction of factors of competitiveness, positively affecting innovative activity.

\section{References:}

1. Verush, A. I. (2012). Natsional'naya bezopasnost'. Minsk, 112.

2. Nyukhnya, I. V. (2015). Bednost' kak ugroza ekonomicheskoi bezopasnosti gosudarstva: metodicheskie aspekty i sistemnye realii. Sotsial'no-ekonomicheskie yavleniya i protsessy, (10), 98104.

3. Arbuzov, S. G. (2016). Sotsial'naya differentsiatsiya obshchestva kak ugroza ekonomicheskoi bezopasnosti gosudarstva: po materialam Ukrainy. Obshchestvo: politika, ekonomika, parvo, (12), 75-77.

4. Shvaiba, D. (2019). Dynamic regression models of forecasting indicators of social and economic security. Bulletin of Science and Practice, 5(1), 249-257.

5. Shvaiba, D. (2018). Industry of the Republic of Belarus: problems of social and economic security. Bulletin of Science and Practice, 4(9), 245-252.

6. Bogatye i bednye - vchera i segodnya. Vserossiiskii tsentr izucheniya obshchestvennogo mneniya. Available at: https://wciom.ru/index.php?id=236\&uid=115317, accessed 16.05.2016.

7. Vakhtina, M. A. (2014). Model' institutsional'nykh rezhimov legitimnosti i ee prakticheskoe primenenie. J. ofInstitutional Studies, 6(2), 58-67.

8. Vakhtina, M. A. (2013). Institutsional'nye osnovaniya spravedlivoi rynochnoi ekonomiki. Samara, 265.

9. Ivanov, Yu. 2008. O global'nom mezhdunarodnom sopostavlenii VVP 146 stran mira. Voprosy ekonomiki, (5), 22-35.

10. Asadzuma, Yu. (2005). Yaponskaya ekonomika 'myl'nogo puzyrya' i ee krakh. Problemy teorii i praktiki upravleniya, (3), 18-23.

\section{Список литературы:}

1. Веруш А. И. Национальная безопасность. Минск, 2012. 112 с. 
2. Нюхня И. В. Бедность как угроза экономической безопасности государства: методические аспекты и системные реалии // Социально-экономические явления и процессы. 2015. №10. C. 98-104.

3. Арбузов С. Г. Социальная дифференциация общества как угроза экономической безопасности государства: по материалам Украины // Общество: политика, экономика, право. 2016. №12. C. 75-77.

4. Shvaiba D. Dynamic regression models of forecasting indicators of social and economic security // Бюллетень науки и практики. 2019. Т. 5. №1. С. 249-257.

5. Shvaiba D. Industry of the Republic of Belarus: problems of social and economic security // Бюллетень науки и практики. 2018. Т. 4. №9. С. 245-252.

6. Богатые и бедные - вчера и сегодня // Всероссийский центр изучения общественного мнения. Режим доступа: https://wciom.ru/index.php?id=236\&uid=115317 (дата обращения: 16.05.2016).

7. Вахтина М. А. Модель институциональных режимов легитимности и ее практическое применение // J. Of institutional Studies. 2014. Т. 6. №2. С. 58-67.

8. Вахтина М. А. Институциональные основания справедливой рыночной экономики. Самара, 2013. 265 c.

9. Иванов Ю. О глобальном международном сопоставлении ВВП 146 стран мира // Вопросы экономики. 2008. №5. С. 22-35.

10. Асадзума Ю. Японская экономика «мыльного пузыря» и ее крах // Проблемы теории и практики управления. 2005. №3. С. 18-23.

Работа поступила

в редакциию 22.06.2019 г.
Принята к публикации 27.06.2019 2.

Ссылка для циитирования:

Shvaiba D. Japanese Experience in Ensuring Social and Economic Security in the National Security System of the Country // Бюллетень науки и практики. 2019. Т. 5. №8. С. 107-113. https://doi.org/10.33619/2414-2948/45/12

Cite as (APA):

Shvaiba, D. (2019). Japanese Experience in Ensuring Social and Economic Security in the National Security System of the Country. Bulletin of Science and Practice, 5(8), 107-113. https://doi.org/10.33619/2414-2948/45/12 (in Russian). 